\title{
PENGARUH MODEL PEMBELAJARAN BERBASIS MASALAH DENGAN STRATEGI ROTATING TRIO EXCHANGE TERHADAP HASIL BELAJAR FISIKA PESERTA DIDIK KELAS XI SMAN 1 LINGSAR TAHUN AJARAN 2017/2018
}

\author{
Wina Mustika*, Susilawati, I Wayan Gunada \\ Program Studi Pendidikan Fisika, Universitas Mataram \\ *Email: winamustika1605@gmail.com
}

\begin{abstract}
This study aims to understand the influence of a problem based learning model using rotating trio exchange strategy (RTE) towards students physics learning achievement of year XI MIA SMAN 1 Lingsar. This study is quasi experiment with Non-equivalent control group design. The population of this study was the whole students of year XI MIA SMAN 1 Lingsar of the academic year 2017/2018 whose total is 89 students. The sampling technique of the study was purposive sampling, which in turn, year XI MIA 1 treated as experimental class and year XI MIA 2 as the control class. The instrument used was a multiple choice test and observation. The multiple choice refers to the cognitive ability of the students (C1-C6) which was 35 items in total which has been tested for validity, reliability, appropriateness, and the level of its difficulty have been examined. Evaluate students' affective and psychomotoric assessments using observation sheets. Based on the result of the study it was gained that students average score of pre-test of both experimental and control class was 42 and 23, while the average score of post-test of both experimental and controlled class was 70 and 67 subsequently. The data gained has been previously examined its normality and homogeneity. It was obtained that experimental and control class was distributed normally and homogeneous. The hypothesis was examined using statistical analysis, i.e. parametric t-test polled variant with $t$ test of both sides. It is obtained that dan diperoleh $t_{\text {hitung }} 1.718$ and $t_{\text {tabel }} \geq 1.683$ on the level of significant $5 \%$. The value of $t_{\text {hitung }}$ is bigger from $t_{\text {tabel }}$, then $H_{o}$ is rejected and $H_{a}$ is accepted. The result indicated that there was positive influence of a problem based model using rotating trio exchange (RTE) strategy towards the students achievement on physics in year XI MIA of SMAN 1 Lingsar.
\end{abstract}

Keywords: problem based learning model, rotating trio exchange, learning achievement.

\section{PENDAHULUAN}

Fisika merupakan ilmu pengetahuan alam yang terus mengalami perkembangan. Fisika mempelajari gejala-gejala alam dan peristiwa alam baik yang dapat dilihat maupun yang bersifat abstrak. Konsep fisika yang abstrak sering kali menjadi kendala bagi guru dalam menyampaikan materi kepada peserta didik, sehingga peserta didik belum optimal dalam memahami konsep yang disajikan (Suranti et al., 2016). Peserta didik yang mempelajari Fisika harus dibantu dalam pengembangan potensi dirinya, serta dibekali keterampilan sehingga mampu berkreasi dan menyelesaikan permasalahan yang dihadapi (Gunawan et al., 2017). Oleh karena itu, diharapkan dalam pembelajaran fisika sebaiknya menghadapkan peserta didik pada permasalahan yang berkaitan dengan konsep-konsep fisika untuk memecahkan masalah (Aziz, et. al., 2014). Menurut Kurniawan, et. al. (2013) dalam pembelajaran fisika terdapat hakikat fisika yang tidak terpisahkan, yaitu fisika sebagai produk (berupa fakta, konsep, prinsip, hukum dan teori), fisika sebagai proses (kerja ilmiah) dan fisika sebagai sikap ilmiah (teliti, jujur, toleran dan bertanggung jawab). Jadi, pelajaran fisika adalah pelajaran yang mengajarkan berbagai permasalahan yang berkaitan dengan konsep-konsep fisika dengan mengembangkan hakikat fisika dalam pembelajaran yang dibangun atas dasar sikap ilmiah sehingga pembelajaran fisika akan mudah dipahami dan lebih menarik bagi peserta didik untuk mencapai tujuan yang diharapkan. 
Pencapaian tujuan yang diharapkan terutama ditentukan oleh pembelajaran yang dialami peserta didik dengan ketepatan model pembelajaran yang digunakan oleh guru ketika pembelajaran fisika. Peserta didik yang belajar dengan model pembelajaran yang tepat akan mengalami perubahan ke arah yang lebih baik, baik dari segi pengetahuan, keterampilan, maupun sikap. Banyak peserta didik yang tidak begitu memperhatikan penjelasan guru karena kebanyakan disuguhkan dalam bentuk persamaan matematis, sehingga pemahaman konsep fisika peserta didik kurang. Hal ini terjadi karena proses pembelajaran yang dirancang masih belum efektif, baik dari segi model pembelajaran, metode pembelajaran, maupun media pembelajaran.

Berdasarkan hasil observasi peneliti melalui wawancara dengan salah seorang guru dan beberapa peserta didik SMAN 1 Lingsar tahun ajaran 2016/2017, diperoleh informasi bahwa peserta didik tidak memperhatikan guru, disebabkan oleh faktor yang berasal dari peserta didik seperti sikap dan minat mereka terhadap pelajaran fisika, mereka beranggapan bahwa pelajaran fisika itu sulit, sehingga peserta didik merasa jenuh dan kurang serius dalam mengikuti proses pembelajaran karena beberapa peserta didik malas bertanya jika tidak mengerti materi yang diajarkan. Sehingga kenyataan yang dapat dilihat bahwa berdampak pada hasil belajar fisika peserta didik yang rendah. Permasalahan ini dapat diselesaikan dengan menggunakan model pembelajaran yang sesuai dengan kemampuan peserta didik

Model pembelajaran yang dapat menjadi solusi menurut peneliti adalah model pembelajaran berbasis masalah dengan strategi rotating trio exchange (RTE). Pembelajaran berbasis masalah adalah model pembelajaran yang menantang peserta didik untuk "belajar bagaimana belajar", bekerja secara kelompok untuk mencari solusi dari permasalahan. Menurut Arends dalam Novriyanti dan Derlina (2014), model pembelajaran berbasis masalah merupakan model pembelajaran yang menyuguhkan berbagai situasi bermasalah yang autentik dan bermakna kepada peserta didik, yang dapat berfungsi sebagai batu loncatan untuk investigasi dan penyelidikan. Oleh sebab itu, peserta didik tidak saja harus memahami konsep yang relevan dengan masalah yang menjadi pusat perhatian tetapi juga memperoleh pengalaman belajar yang berhubungan dengan kemampuan berpikir dan belajar kelompok dalam memecahkan masalah serta menumbuhkan pola berpikir kritis. Hal ini didukung oleh penelitian yang dilakukan oleh Firmansyah. A, et. al. (2015) bahwa model pembelajaran berbasis masalah berpengaruh signifikan terhadap hasil belajar fisika peserta didik.

Fisika sebagai produk, proses, dan sikap dalam pembelajarannya membutuhkan startegi pembelajaran yang dapat mengefektifkan proses pembelajaran yang dapat merangsang pikiran, perasaan dan perhatian dari peserta didik pada saat proses belajar mengajar berlangsung. Salah satu strategi yang cocok digunakan yaitu strategi (RTE). RTE merupakan strategi yang digunakan dalam diskusi tentang berbagai masalah dengan teman kelasnya. Dalam strategi ini akan terjadi perputaran atau pertukaran anggota kelompok sehingga akan terbentuk kelompok-kelompok baru pada setiap pergantian masalah atau pertanyaan (Frensista, et. al., 2014). Pertukaran ini dapat dengan mudah dilengkapi dengan materi pelajaran. Mulatsari, et. al., (2016) menyatakan bahwa strategi pembelajaran RTE dapat membuat peserta didik lebih aktif dan mempermudah mereka dalam memahami materi yang diajarkan. Dengan adanya proses perputaran anggota kelompok dalam mengkonstruksi konsep fisika, diharapkan dapat membangkitkan keaktifan 
peserta didik sehingga tercipta pembelajaran yang bermakna. Frensista, et. al. (2014) menyatakan bahwa strategi (RTE) merupakan startegi yang digunakan dalam diskusi tentang berbagai masalah dengan beberapa teman sekelasnya.

Model pembelajaran berbasis masalah menekankan metode instruksional yang menantang peserta didik agar belajar untuk belajar, bekerja sama dalam kelompok untuk mencari solusi bagi masalah yang nyata, strategi (RTE) pun dapat membuat belajar lebih menarik, interaktif dan aktif. Jadi kolaborasi antara model pembelajaran berbasis masalah dengan strategi (RTE), diharapkan dapat menciptakan proses pembelajaran yang efektif agar peserta didik sembari menguji pemikirannya, empertanyakan, mengkritisi gagasannya sendiri, sekaligus mengeksplor hal yang baru sehingga kesan membosankan dalam pembelajaran fisika dapat teratasi. Selain itu, peserta didik dapat berperan aktif karena peserta didik berpartisipasi langsung dalam proses pembelajaran sehingga dapat berpengaruh pada hasil belajar peserta didik. Berdasarkan paparan diatas, maka peneliti tertarik untuk melakukan penelitian berjudul "Pengaruh Model Pembelajaran Berbasis Masalah dengan Strategi Rotating Trio Exchange (RTE) terhadap Hasil Belajar Fisika Peserta didik “.

\section{METODE PENELITIAN}

Desain dari penelitian kuasi eksperimen ini menggunakan nonequivalent control group design with pretest-and post-test. Suatu penelitian memiliki beberapa variabel penelitian sehingga pembaca dapat mengetahui alur dari sebuah eksperimen. Penelitian ini melibatkan variabel bebas yaitu model pembelajaran berbasis masalah dengan strategi RTE, variabel terikat yaitu hasil belajar fisika, dan variabel kontrol yaitu waktu, guru yang mengajar dan materi ajar.
Penelitian ini dilakukan di SMA Negeri 1 Lingsar. Populasi penelitian adalah 4 kelas. Sampel penelitian adalah kelas XI MIA 121 peserta didik dan kelas XI MIA 2 sebanyak 22 peserta didik. Pemilihan sampel ditentukan dengan purposive sampling, dimana harus ada sebab khusus dalam pengambilan sampel. Sebab peneliti mengambil kelas XI MIA 1 dan kelas XI MIA 2 sebagai sampel adalah karena dari 4 kelas XI pada sekolah tersebut, nilai ratarata UAS kelas XI MIA1 dan kelas XI MIA 2 memiliki perbedaan yang sangat tipis, secara berturut-turut nilainya adalah 63,20 dan 63,25. Nilai tersebut kurang dari KKM yaitu 75,00 .

Instrumen yang digunakan adalah tes pilihan ganda sebanyak 35 soal. Instrumen tes pilihan ganda sebelum digunakan harus memenuhi beberapa syarat yaitu uji validitas, uji reliabilitas, tingkat kesukaran soal dan daya beda. Uji statistik parametrik yang digunakan adalah uji-t Polled Variant dengan taraf signifikan 5\% dan harga t tabel dihitung dari selisih harga $\mathrm{t}$ tabel dengan $d k=n_{1}-1$ dan $d k=n_{2}-1$, dibagi dua dan kemudian ditambah dengan harga t yang terkecil

\section{HASIL DAN PEMBAHASAN}

Penelitian ini bertujuan untuk mengetahui apakah ada pengaruh model pembelajaran berbasis masalah dengan strategi rotating trio exchange $\mathrm{RTE}$ terhadap hasil belajar fisika peserta didik kelas XI. Penelitian ini dilakukan sebanyak enam kali pertemuan pada kelas eksperimen dan kelas kontrol. Pertemuan pertama diberikan tes awal pada kedua kelas, pertemuan kedua sampai kelima diberikan perlakuan yang berbeda yaitu, kelas eksperimen diberikan perlakuan dengan model pembelajaran berbasis masalah dengan strategi RTE dan pada kelas kontrol dengan pembelajaran langsung. Pertemuan keenam dengan memberikan tes akhir untuk kedua kelas. 
Data yang diperoleh dalam penelitian ini adalah data yang terkumpul dari hasil tes awal dan tes akhir. Tes awal diberikan pada kelas eksperimen dan kelas kontrol yang bertujuan untuk mengetahui kemampuan awal peserta didik sebelum diberi perlakuan. Tes akhir bertujuan untuk mengetahui kemampuan akhir kedua kelas setelah diberikan perlakuan.

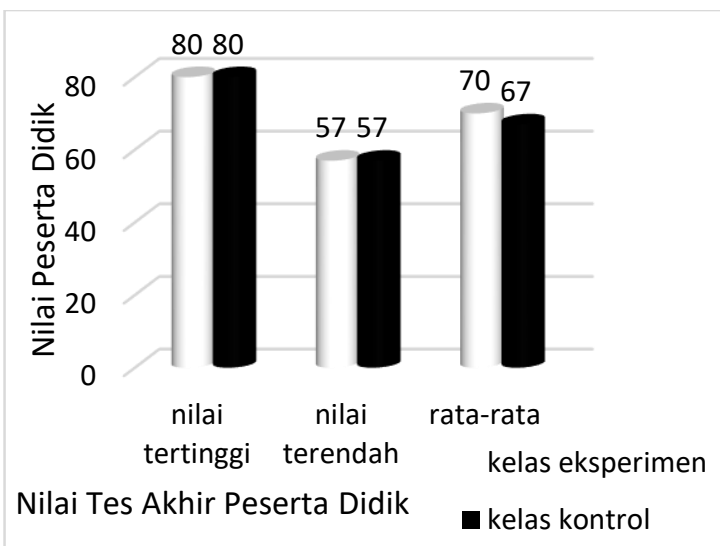

Gambar 1. Hasil Belajar Tes Akhir Peserta Didik

Data penelitian hasil belajar fisika peserta didik terdiri dari hasil tes awal dan tes akhir berupa deskripsi data hasil belajar kogntif dengan cara uji normalitas, homogenitas, dan uji hipotesis dan deskripsi data afektif serta psikomotor.

Data hasil posttest peserta didik disajikan dalam histogram pada Gambar 1 berikut. Gambar 1 menunjukkan bahwa nilai tertinggi di kelas eksperimen dan kontrol adalah 80. Nilai terendah untuk kedua kelas sendiri adalah 57. Selain itu, nilai rata-rata peserta didik untuk kelas eksperimen dan kontrol berturut-turut adalah 70 dan 67 . Hasil tes akhir yang berbeda pada kedua kelompok sampel menunjukkan adanya peningkatan nilai setelah diberikan perlakuan salama proses pembelajaran.

Penilaian hasil belajar pada ranah afektif untuk kelas kontrol dan kelas eksperimen diamati secara individu oleh observer untuk setiap peserta didik. Hasil belajar pada ranah afektif peserta didik diukur berdasarkan kriteria tertentu. Lembar observasi untuk ranah afektif ini diisi oleh observer dengan memberikan tanda checklist pada kolom yang tersedia berdasarkan indikator yang dinilai pada lembar observasi tersebut. Indikatorindikator tersebut berupa rasa ingin tahu, kerja sama, jujur, kritis dan kagum akan kebesaran Tuhan.

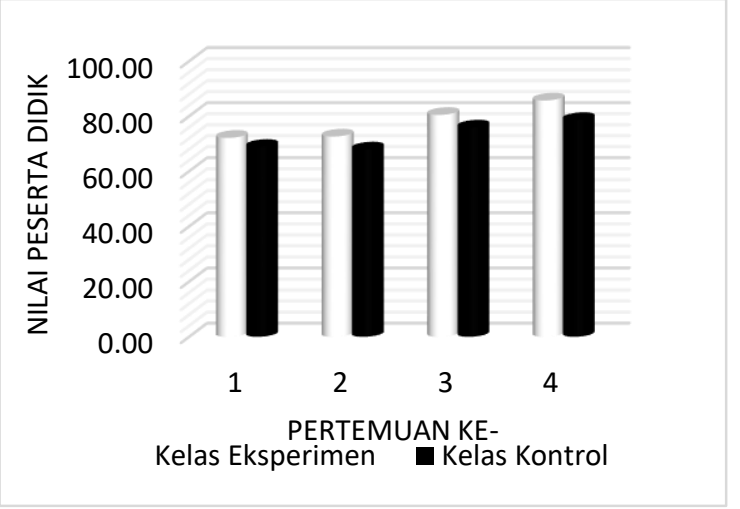

Gambar 2. Histogram Hasil Belajar Pada Ranah Afektif Kelas Eksperimen Dan Kelas Kontrol

Penilaian hasil belajar pada ranah psikomotor untuk kelas kontrol dan kelas eksperimen diamati secara kelompok oleh observer. Ranah psikomotor yang diteliti dalam penelitian ini meliputi aspek visualisasi dan konten sesuai dengan yang tertera pada lembar kerja peserta didik (LKPD), mampu dalam bertanya, menanggapi serta mengkomunikasikan hasil diskusi dengan baik dalam bentuk presentasi.

Pada pertemuan pertama sampai pertemuan keempat nilai rata-rata yang diperoleh kelas kontrol sebeser; 60\%, 67\%, $70 \%$ dan $81 \%$. Berdasarkan nilai persentase kelas kontrol juga memiliki kategori yang berbeda-beda setiap pertemuannya. Pada pertemuan pertama dan kedua persentase nilai peserta didik berada pada kategori cukup baik, untuk pertemuan ketiga persentase nilai peserta didik berada pada kategori baik, dan pertemuan keempat 
persentase nilai peserta didik meningkat yaitu berada pada kategori sangat baik. Agar lebih jelas dapat dilihat pada Gambar 3 berikut.

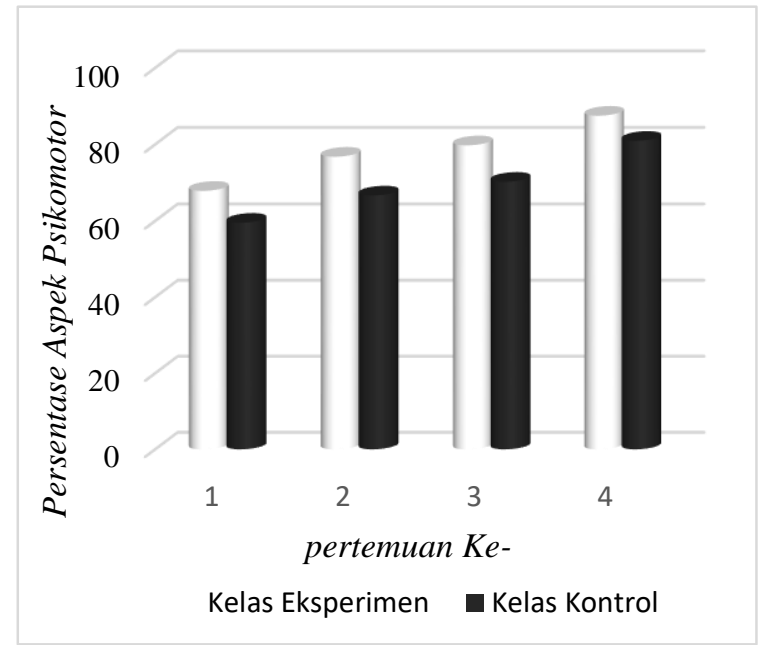

Gambar 3. Histogram Hasil Belajar Psikomotor Kelas Eksperimen Dan Kelas Kontrol

Penelitian ini mengukur hasil belajar pada ranah kognitif yaitu C1 sampai C6, ranah afektif, dan ranah psikomotor bertujuan untuk menguji pengaruh penggunaan model berbasis masalah dengan strategi RTE terhadap hasil belajar fisika peserta didik kelas XI SMAN 1 Lingsar. Terdapat dua kelompok sampel, yaitu kelas XI MIA 1 sebagai kelas eksperimen yang berjumlah 21 peserta didik dan kelas XI MIA 2 sebagai kelas kontrol sejumlah 22 peserta didik. Kegiatan yang dilakukan dengan memberikan perlakuan berupa penerapan model berbasis masalah dengan strategi RTE pada kelas eksperimen dan perlakuan berupa penerapan model pembelajaran langsung pada kelas kontrol. Kedua kelas diberikan perlakuan selama empat kali pertemuan dengan alokasi waktu setiap pertemuan selama 90 menit (2 jam pelajaran). Sebelum diberikan perlakuan kedua kelas diberikan tes awal yang bertujuan untuk mengetahui kemampuan awal siswa pada kedua kelas.
Hasil belajar fisika peserta didik yang dimaksud pada penelitian ini adalah hasil belajar pada ranah kognitif $\mathrm{C} 1$ sampai C6 (mengingat, memahami, mengaplikasi, menganalisis, mengevaluasi dan mencipta) yang diteliti pada materi suhu, kalor, dan perpindahan kalor. Pengambilan data untuk data kemampuan awal dan akhir dilakukan dengan memberikan tes, yaitu tes awal dan tes akhir. Tes berupa tes obyektif dengan bentuk tes pilihan ganda sebanyak 35 soal. Sebelum mendapatkan 35 soal, peneliti melakukan uji validitas soal pada kelas XII IPA 1 dengan membuat 40 soal. Pada hasil uji coba instrumen terdapat 35 soal yang diterima, 11 soal yang direvisi dan 5 soal ditolak. Sehingga peneliti menyimpulkan untuk mengambil 35 soal tersebut untuk diberikan ke peserta didik pada saat melakukan tes awal dan tes akhir.

Data hasil penelitian, menunjukkan bahwa nilai rata-rata tes awal peserta didik pada kelas eksperimen sebesar 42 dan kelas kontrol sebesar 23. Setelah kedua kelas diberi perlakuan, data untuk tes akhir diperoleh bahwa nilai rata-rata hasil belajar fisika kelas eksperimen sebesar 70 dengan nilai tertinggi 80 dan nilai terendah 57. Kelas kontrol nilai rata-rata tes akhir sebesar 67 dengan nilai tertinggi 80 dan nilai terendah 57. Nilai rata-rata tes akhir menunjukkan bahwa kemampuan memecahkan masalah fisika pada pokok bahasan suhu, kalor dan perpindahan kalor kelas eksperimen dan kelas kontrol mengalami peningkatan dari yang diperoleh sebelumnya.

Berdasarkan hasil uji homogenitas kedua kelas adalah homogen dan data terdistribusi normal, selanjutnya dilakukan analisis data uji hipotesis menggunakan uji-t polled varians didapatkan $t_{\text {hitung }}=1.718$ dan $t_{\text {tabel }} 1.683$ pada taraf signifikan $5 \%$ untuk derajat kebebasan $41\left(d k=n_{1}+n_{2}-\right.$ $2=21+22-2=41)$. Berdasarkan kriteria pengujian $t_{\text {hitung }}>t_{\text {tabel }}$, yaitu $1.718>1.683$, sehingga dapat disimpulkan $\mathrm{H}_{\mathrm{o}}$ ditolak dan 
$\mathrm{H}_{\mathrm{a}}$ diterima. Dengan demikian, dapat disimpulkan bahwa model pembelajaran berbasis masalah dengan strategi RTE berpengaruh te rhadap hasil belajar fisika peserta didik kelas XI MIA SMAN 1 Lingsar. Hal ini menunjukkan bahwa model pembelajaran berbasis masalah dengan strategi RTE yang diterapkan pada kelas eksperimen memberi pengaruh yang signifikan terhadap hasil belajar peserta didik dibandingkan dengan pembelajaran langsung yang diterapkan di kelas kontrol.

$$
\text { Hasil penelitian mengenai }
$$

kemampuan kognitif berupa hasil belajar terdapat beberapa penelitian lain, baik itu pengaruh model pembelajaran berbasis masalah dan strategi RTE. Hasil penelitian yang dilakukan oleh Aziz, et. al. (2015) menyatakan bahwa terdapat perbedaan yang signifikan antara hasil belajar fisika siswa yang diajar dengan model pembelajaran berbasis masalah dengan hasil belajar fisika siswa yang diajar melalui pembelajaran yang konvensional kelas X SMAN 1 Gunungsari T.P 2014/2015. Penelitian Gunada (2015) menyatakan bahwa pembelajaran berbasis masalah lebih efektif untuk meningkatkan keterampilan berpikir kritis dan hasil belajar kelompok mahasiswa. Sedangkan penelitian Setiyani, et. al. (2015) menyatakan bahwa terdapat pengaruh model pembelajaran RTE dengan Questions Box terhadap hasil belajar siswa kelas X SMA Negeri 1 Karanganyar T.P 2014/2015. Penelitian Nuraeni dan Afriansyah (2016) mengatakan bahwa peningkatan kemampuan pemahaman siswa melalui pembelajaran kooperatif tipe RTE, dinyatakan efektif dalam meningkatkan keaktifan siswa dan siswa mampu menemukan ide-ide baru sehingga memberikan penguatan pada kemampuan pemahaman konsep matematis yang telah dipelajari. Penelitian-penelitian para peneliti tersebut membuktikan bahwa model pembelajaran berbasis masalah dengan strategi RTE merupakan suatu yang melibatkan beberapa manipulasi pengetahuan di dalam struktur kognitif dan aktivitas berpikir diarahkan untuk memecahkan masalah dalam kehidupan sehari-hari serta melibatkan peserta didik dalam bekerja kelompok untuk menemukan ide-ide baru sehingga memberikan peningkatan pada hasil belajar dan terjadi proses belajar yang bermakna.

Pembelajaran berbasis masalah merupakan model pembelajaran yang menghadapkan peserta didik pada suatu masalah di awal pembelajaran, dan masalah ini menjadi fokus pembelajaran untuk dicari pemecahan masalahnya oleh peserta didik secara langsung dalam kelompok-kelompok tertentu. Seperti dalam penelitian Nissa (2014) bahwa pembelajaan berbasis masalah menuntut aktivitas mental siswa dalam memahami suatu konsep, prinsip, dan keterampilan melalui situasi atau masalah yang disajikan di awal pembelajaran yang menggunakan pendekatan masalah kontekstual sebagai sarana bagi siswa untuk belajar berpikir kritis sehingga penegetahuan dan konsep yang penting dari materi pelajaran menjadi bermakna. Sedangkan startegi RTE adalah salah satu strategi pembelajaran aktif yang digunakan untuk mendiskusikan permasalahan bersama teman sekelas dan rotating trio exchange ini sering disebut dengan merotasi pertukaran pendapat kelompok tiga orang. Berdasarkan hasil penelitian ini dapat dilihat bahwa model pembelajaran berbasis masalah dengan strategi RTE memberi pengaruh yang positif dan signifikan terhadap hasil belajar peserta didik, karena setiap sintak yang ada pada model pembelajaran berbasis masalah dengan strategi RTE dilaksanakan dengan baik dan terstruktur oleh peneliti pada saat proses mengajar, hal ini dapat dilihat pada lampiran 38 berdasarkan pada hasil pengamatan yang dilakukan oleh observer selama proses pembelajaran pada kelas eksperimen. 
Sintak model pembelajaran berbasis masalah dengan strategi RTE melakukan orientasi masalah kepada peserta didik. Hal ini, efektif dalam membantu memicu kemampuan memecahkan masalah yang akan di diskusikan pada LKPD, dan membantu dalam memfokuskan perhatian peserta didik, sehingga proses belajar menjadi kondusif dan terstruktur dengan baik. Pendapat ini didukung oleh Amir (2009) yang mengatakan bahwa pembelajaran berbasis masalah merupakan proses pembelajaran yang menuntun peserta didik mendapatkan pengetahuan yang penting untuk memicu rasa keingintahuan serta kemampuan analisis, inisiatif untuk menghubungkan materi baru dengan konsep yang sesuai dengan struktur kognitif.

Sintak kedua model pembelajaran berbasis masalah dengan strategi RTE mengorganisasikan peserta didik untuk membentuk kelompok trio atau yang terdiri dari 3 orang dan diberikan sebuah pertanyaan atau masalah yang sama untuk setiap trio untuk didiskusikan. Penyajian bahaan ajar, selanjutnya dengan cara diskusi kelompok trio menggunakan LKPD, yang dapat membantu peserta didik untuk memiliki pengalaman belajar yang nyata dan aktif, sehingga peserta didik dapat lebih memahami konsep-konsep pada materi suhu, kalor, dan perpindahan kalor.

Sintak ketiga model pembelajaran berbasis masalah dengan strategi RTE membimbing penyelidikan individu maupun kelompok pada fase ini peneliti membimbing setiap kelompok trio untuk mendiskusikan masalah yang pertama kemudian guru meminta semua trio untuk memberi nomor 0,1 atau 2 kepada setiap anggotanya. Peneliti mengarahkan peserta didik bernomer 1 untuk pindah sejauh satu trio searah jarum jam. Kemudian peserta didik bernomor 2 pindah sejauh dua trio searah jarum jam. Kemudian peneliti meminta peserta didik dengan nomor 0 tetap duduk di tempatnmya karena mereka merupakan anggota permanen di setiap trio. Murid-murid bernomor 0 diminta mengangkat tangannya tinggi-tinggi sehingga murid-murid yang pindah tempat dapat melihatnya dengan mudah. Hasilnya adalah trio-trio yang seluruhnya baru dan memulai diskusi baru dengan pertanyaan baru. Sintak keemapat mengembangkan dan mempresentasikan hasil yang telah di diskusikan pada LKPD. Sintak kelima menganalisis dan mengevaluasi proses pemecahan masalah, pada sintak kelima ini peneliti memberikan penguatan/penjelasan lanjut terhadap konsep yang di diskusikan oleh peseta didik dan memberikan penghargaan kepada peserta didik yang berperan aktif selama proses pembelajaran berlangsung.

Pembelajaran langsung yang diterapkan dikelas kontrol, karena menggunakan metode ceramah dan langsung membahas contoh soal, sehingga peserta didik menjadi kurang aktif dan proses pembelajaran hanya berpusat pada guru. Hal inilah, yang menyebabkan pemahaman konsep fisika menjadi rendah yang berdampak pada hasil belajar fisika yang rendah.

Berdasarkan lembar observasi yang telah diamati dan dinilai oleh observer selama proses pembelajaran untuk ranah afektif dan psikomotor, menunjukan bahwa model pembelajaran berbasis masalah dengan strategi RTE berpengaruh pada ranah afektif dan ranah psikomotor yang signifikan, jika dibandingkan dengan pembelajaran langsung yang diterapkan di kelas kontrol. Pada kelas eksperimen menggunakan lembar kerja peserta didik LKPD yang telah disediakan selama empat kali perpenelitian sedangkan kelas kontrol mengerjakan latihan soal.

Hasil penilaian ranah afektif pada kelas eksperimen dan kelas kontrol, menunjukkan terdapat perbedaan yang 
signifikan selama proses pembelajaran, peserta didik pada kelas eksperimen memiliki rata-rata yang lebih tinggi dari pada kelas kontrol yaitu 77.73 dan 72.84 . Hal tersebut karena peserta didik pada kelas eksperimen dituntut untuk aktif dalam proses belajar, dibandingkan dengan kelas kontrol yang pasif dimana proses belajarnya berpusat pada guru, sehingga peseta didik menjadi kurang bersemangat dalam proses belajar. Menurut Supardi (2015), proses pembelajaran pada ranah afektif menekankan pada bagaimana kepribadian peserta didik bersikap dan bertingkah laku serta menghargai orang lain selama proses pembelajaran. Berdasarkan hasil pengamatan yang dilakukan observer selama kegiatan pembelajaran, peneliti menyimpulkan bahwa hasil belajar fisika pada ranah afektif, peserta didik pada kelas eksperimen lebih menonjol dari pada kelas kontrol.

Sedangkan aspek yang dinilai pada ranah psikomotor menunjukkan bahwa penilaian hasil visualisasi yaitu terhadap hasil presentasi dan konten atau isi lembar kegiatan yang sudah dikerjakan menunjukkan bahwa kelas eksperimen juga lebih baik daripada kelas kontrol. Berdasarkan hasil pengamatan yang telah dilakukan, menunjukkan bahwa keterampilan peserta didik selama kegiatan pembelajaran mengalami peningkatan yang baik pada setiap perpenelitian, baik pada kelas eksperimen maupun kelas kontrol. Pada perpenelitian pertama pada kelas eksperimen, peserta didik yang belum terbiasa melakukan diskusi kelompok dengan merotasi dan mengerjakan LKPD yang berbentuk permasalahan, sehingga membutuhkan bimbingan dari guru. Pada perpenelitian selanjutnya, peserta didik sudah cukup terbiasa mengikuti proses pembelajaran dengan baik. Seluruh kelompok dalam proses pembelajaran semakin aktif dan peserta didik mampu menemukan ide-ide baru sehingga memberikan penguatan pada kemampuan pemecahan masalah yang telah dipelajari. Sedangkan pada kelas kontrol juga pada perpenelitian pertama sampai keempat mengalami peningkatan selama prose pembelajaran, walaupun banyak peserta didik yang masih asyik sendiri tanpa tahu apa yang akan di kerjakan. Supardi (2015) juga menyatakan bahwa pembelajaran keterampilan akan efektif bila dilakukan dengan menggunakan prinsip belajar sambil mengerjakan (learning by doing) dan keterampilan yang dilatih melalui praktik secara berulang-ulang akan menjadi kebiasaan.

Data hasil penilaian afektif dan psikomotor dapat mempengaruhi hasil belajar peserta didik pada ranah kognitif, terlihat dari pencapaian rata-rata hasil tes akhir (posttest) peserta didik kelas eksperimen lebih tinggi daripada kelas kontrol. Hal ini, karena model pembelajaran berbasis masalah dengan strategi RTE memberi hal-hal positif seperti peserta didik lebih semangat serta lebih berkonsentrasi selama diskusi kelompok berlangsung. Pernyataan ini didukung oleh Firmansyah, et al (2015) yang mengatakan bahwa model pembelajarn berbasis masalah dengan metode eksperimen pada materi cahaya dapat meningkatkan aktivitas proses belajar mengajar. Menurut Nuraeni dan Afriansyah (2016) yang menyatakan bahwa peningkatan kemampuan pemahaman matematis siswa melalui pembelajaran kooperatif tipe rotating trio exchange (RTE) dapat mengalami peningkatan dalam pembelajaran dan menciptakan suasana belajar yang menyenangkan dan tidak membosankan. Khanafiyah (2011) juga menyatakan bahwa penerapan model pembelajaran aktif melalui strategi rotating trio excahnge untuk meningkatkan kemampuan analisis dan aktivitas belajar siswa SMA kelas $\mathrm{X}$ semester II pokok 
bahasan kalor dapat meningkatkan aktivitas belajar siswa secara signifikan.

Berdasarkan hasil penelitian sebelumnya dan hasil penelitian peneliti terbukti memiliki kecocokan. Hasil penelitian menunjukkan3 bahwa model pembelajaran berbasis masalah dengan strategi RTE memberi pengaruh yang signifikan terhadap hasil belajar fisika peserta didik kelas XI MIA SMAN 1 Lingsar. Pengaruh pada hasil belajar tidak hanya pada ranah kognitif saja, namun pada ranah afektif dan ranah psikomotor juga memberi dampak yang positif dan signifikan.

\section{PENUTUP}

Berdasarkan hasil penelitian, analisis data, dan pembahasan, dapat disimpulkan bahwa, terdapat pengaruh model pembelajaran berbasis masalah dengan strategi RTE terhadap hasil belajar fisika peserta didik kelas XI MIA SMAN 1 Lingsar. Pengaruh tersebut menunjukkan adanya peningkatan hasil belajar pada materi suhu, kalor, dan perpindahan kalor, baik pada ranah kognitif (C1 sampai C6), ranah afektif dan ranah psikomotor. Pengaruh tersebut juga menunjukkan bahwa, setiap sintak yang ada pada model pembelajaran berbasis masalah dengan strategi RTE diterapkan dengan baik, sehingga proses pembelajaran pun menjadi bermakna.

Model pembelajaran berbasis masalah dengan strategi RTE dapat menjadi salah satu alternatif model pembelajaran yang diterapkan oleh guru dalam proses mengajar dan saat melakukan model pembelajaran berbasis masalah dengan strategi RTE ini perlu memperhatikan durasi pembelajaran agar pelaksanaan pembelajaran menjadi kondusif. Untuk memperoleh hasil yang lebih baik maka perlu diadakan perbaikan. Misalnya alokasi waktu dapat diatur sebaik mungkin sehingga tiap tahapan pembelajaran dapat berlangsung optimal serta mengetahui karekteristik peserta didik, teknik pengelolaan kelas, dan faktor-faktor lain yang berpengaruh terhadap hasil belajar peserta didik.

\section{REFERENSI}

Amir, M. T. 2009. Inovasi Pendidikan Melalui Problem Based Learning. Jakarta: Kencana Prenadamedia Group.

Aziz, A, Rokhmat, J dan Kosim. 2014. Pengaruh Model Pembelajaran Berbasis Masalah dengan Metode Eksperimen terhadap Hasil Belajar Fisika Peserta didik Kelas X SMAN 1 Gunung Sari Kabupaten Lombok Barat Tahun Pelajaran 2014/2015. Jurnal Pendidikan Fisika dan Teknologi (JPFT), 1(3): 200-204.

Firmansyah, A, Kosim dan Ayub, S. 2015. Pengaruh Model Pembelajaran Berbasis Masalah dengan Metode Eksperimen pada Materi Cahaya terhadap Hasil Belajar Fisika Peserta didik Kelas VIII SMPN 2 Gunungsari Tahun Ajaran 2014/2015. Jurnal Pendidikan Fisika dan Teknologi (JPFT), 1(3): 154159.

Frensista, D, Trapsilasiwi, D dan Nurcholif, D, S, L. 2014. Penerapan Model Pembelajaran Kooperatif dengan Strategi Rotating Trio Exchange (RTE) untuk Meningkatkan Hasil Belajar Peserta didik Kelas VII A pada Sub Pokok Bahasan Keliling dan Luas Bangun Segitiga dan Segiempat di SMPN 1 Ajung Semester Genap Tahun Ajaran 2012/2013. Jurnal Pendidikan Matematika Jember, 3(2): 43-52.

Gunada, Wayan I. 2015. Pengaruh Model Pembelajaran Berbasis Masalah untuk Meningkatkan Hasil Belajar Fisika Dasar Ditinjau dari Gaya Kognitif Mahasiswa. Jurnal Kependidikan, 13(2):153-161. 
Gunawan, G., Sahidu, H., Harjono, A., \& Suranti, N. M. Y. The Effect of Project Based Learning with Virtual Media Assistance on Student's Creativity in Physics. Cakrawala Pendidikan, (2), 167-179.

Kurniawan, T, Rokhmat, J dan Ardhuha,J. 2013. Perbedaan Hasil Belajar Melalui Penerapan Model Pembelajaran Berbasis Masalah Berbantuan Komik Fisika dengan Pembelajaran Konvensional Pada Peserta didik Kelas VIII SMPN 1 Labuapi Tahun Ajaran 2013/2014. Jurnal Pendidikan Fisika dan Teknologi (JPFT), 1(2): 123-128.

Khanafiyah, S, Arifin. 2011. Penerapan Pembelajaran Aktif Melalui Strategi Rotating Trio Exchange Untuk Meningkatkan Kemampuan Analisis dan Aktivitas Belajar Siswa SMA Kelas X Semester II Pokok Bahasan Kalor. Jurnal Pendidikan Fisika Indonesia (JPFI), 7(2):97-100.

Mulatsari, D, Susanti, E dan Mulyani, B. 2016. Penerapan Model Pembelajaran Rotating Trio Exchange (RTE) Menggunakan Macromedia Flash untuk Meningkatkan Kemampuan Memori dan Prestasi Belajar Kimia pada Materi Sistem Periodik Unsur X SMK Muhammadiyah 2 Sragen Tahun Pelajaran 2013/2014.Jurnal Pendidikan Kimia (JPK), 5(3): 5458.

Nissa, Chairun Ita. 2014. Implementasi Problem Learning dengan Conceptual, Strategic dan Metacognitive Scaffolding Untuk Meningkatkan Kemampuan Siswa SMP Memecahkan Masalah Luas Permukaan Bangun Ruang. Jurnal Kependidikan, 13(2):163-172.

Novriyanti, A dan Derlina. 2014. Pengaruh Model Pembelajaran Berbasis Masalah Terhadap Hasil Belajar Peserta didik pada Materi Pokok Suhu dan Kalor di Kelas X Semester
II SMAN 1 Delitua. Jurnal Inpafi, 2(4).

Nuraeni, Y dan Afriansyah, A. E. 2016. Peningkatan Kemampuan Pemahaman Matematis Siswa Melalui Pembelajaran Kooperatif Tipe Rotating Trio Exchange. Jurnal Inovasi Pendidikan Dasar, 1(2): 4758.

Setiyani, A.W, Maftukhin, A dan Kurniawan, S, E. Pengaruh Model Pembelajaran Rotating Trio Exchange (RTE) dengan Media QUESTIONS Box Terhadap Hasil Belajar Fisika Siswa Kelas X SMA Negeri 1 Karanganyar Tahun Pelajaran 2014/2015. Jurnal Radiasi, 7(1): 57-62.

Silberman, M. 2013. Pembelajaran Aktif 101 Strategi untuk Mengajar Secara Aktif. Jakarta : PT. Indeks.

Supardi. 2015. Penilaian Autentik Pembelajaran Afektif, Kognitif, dan Psikomotor; Konsep dan Aplikasi. Jakarta: PT Raja Grafindo Persada.

Suranti, N. M. Y., Gunawan, G., \& Sahidu, H. (2016). Pengaruh Model Project Based Learning Berbantuan Media Virtual Terhadap Penguasaan Konsep Peserta didik pada Materi Alat-alat Optik. Jurnal Pendidikan Fisika dan Teknologi, 2(2), 73-79. 